\title{
A Fair Critique of European Philosophy?
}

\section{MEYSAM BADAMCHI}

Center for Modern Turkish Studies, Istanbul Şehir University, Turkey (badamchi.m@gmail.com)

This article reviews Hamid Dabashi's "Can Non-Europeans Think?" (2015). It attempts to show that while Dabashi offers a powerful analysis of Iranian and Middle Eastern politics, his arguments turn to be unpersuasive when he aims to radically criticize European philosophy and enlightenment thought.

Keywords: Critique of Post-Colonialism; European Philosophy; Middle East; Hamid Dabashi

HAMID DABASHI, Can Non-Europeans Tbink? London: Zed Books, 2015, 302 pages.

Can Non-Europeans Think? is the third part of a trilogy. The book largely consists of essays Hamid Dabashia professor of Iranian Studies and Comparative Literature at Columbia University—has written for different websites as well-known as Aljazeera, CNN, Al-Ahram, etc. during the last years. Can Non-Europeans Think cannot be considered as an academic work, strictly speaking, though it includes many inspirations useful for academics. The book's chapters are not always related to each other, mainly because they have been written for different occasions over several years. Dabashi's language is sometimes provocative and confrontational, and he even uses satire to overcome his opponent and pursue his argument. As a scholar of comparative literature, his language is not devoid of literary jargon or references to literature and cinema (see for example, 128-33). Dabashi has written this book primarily as a public intellectual, especially in the English-speaking world, and any evaluation of him also needs to be done from this perspective.

\section{A Post-Colonial Critique of European Philosophy}

The book's title is taken from an essay with the same title originally published on the Aljazeera website in response to the leftist Slovenian philosopher Slavoj Žižek, and Žižek's young Spanish defender, Santiago Zabala. Dabashi accuses Žižek and Zabala of being Eurocentric in their outlook, and of underestimating non-European philosophical thinking. Indeed, the same point is emphasized in the 'Foreword' written by the Argentinian intellectual, Walter Mignolo.

One thinker who perhaps has had the deepest influence on Dabashi is the Palestinian-American intellectual Edward Said. The second chapter of the book entitled, "The Moment of Myth: Edward Said, 1935-2003," includes two essays written in the memory of Said one written immediately after his death, and the other on his tenth death anniversary (44-61). As is well known, one of Said's major contributions in his now classic Orientalism is his radical critique of the discipline known as 'Orientalism' in western universities. Dabashi is a Foucaultian-Saidian writer for whom the relationship between power and knowledge is a major occupation, and whose aim is to extend the Foucaultian-Saidian paradigm to areas which have been 
untouched. Particularly, he uses their thought in order to question the legitimacy of those think-tanks in the USA and elsewhere which, according to Dabashi, produce colonial pro-war discourses for neo-conservatives (see: 62-74). Indeed, Dabashi can be considered as the main representative of postcolonial political thought, with all its strengths and weaknesses, of course, among Iranian intellectuals.

Similar to other post-colonialists, Dabashi is a critic of enlightenment and one of its main philosophical representatives, Immanuel Kant. Quoting parts of Kant on aesthetics where the German philosopher discusses the different aesthetical tastes among nations, for example Chinese and Europeans, Dabashi attributes a type of pro-colonialism and hidden racism to Kant. He mentions an anecdote where Kant, facing a black person with fine philosophical scrutiny, says "and it might be that there where something in this [man's words] which perhaps deserved to be considered; but in short, this fellow was quite black from head to foot, a clear proof that what he said was stupid" (quoted by Dabashi: 259). Unfortunately, the source of this unfortunate quotation is not mentioned. In my view, what Dabashi is mainly doing here is selecting and highlighting some parts of Kant without considering their place and significance within the general framework of Kantian overall philosophy. Who can deny that the very idea embedded at the core of Kantian morality-which to put it in Charles Larmore's vocabulary is 'equal respect for persons'-is against the very same racist sentence quoted by Dabashi? How could Kant remain consistent about his morality by denying Africans to be persons? Thus, it seems to be more appropriate to say that in such possible utterances Kant has been contradicting the very foundations of his own moral maxims by adopting a racist language.

Another problem with this type of reading Kant-and perhaps of Žižek-is its essentialism. Here Dabashi seems to be infected by the same flaw which he rightly truly attributes to militant secularists in their encounter with Islam. In other words, Dabashi adopts the same ahistorical and essentialist perspective in his encounter with European philosophy which militant Islamophobes show about religion (See the next section). The central claim of Dabashi in characterizing European thinkers such as Kant and Žižek as "colonial" is that they have obtained their visibility and prominence in philosophical thinking by denying philosophical thinking to others, i.e. Muslims, Africans, South Asians, Latin Americans, etc. Dabashi emphasizes that the point of his criticism is neither to reduce the "multifaceted philosophical tradition" in Europe to those unpleasant revelations, nor to dismiss the entirety of that heritage based on "scattered comments," "nor to cater to a vulgar nativism, which has been one particularly unfortunate by-product of Edward Said's Orientalism" (259). He admits that from within European philosophy itself, "many critical and emancipatory reactions to such racist proclivities have been widely discernible" (ibid.). Yet he is eager to reassert that "what unites Kant, Levinas, and Žižek (among many others) is that their self-universalizing philosophies are invariably predicated on denying others the capacity to think critically or creatively by way of enabling, authorizing, and empowering themselves to think for the world" (ibid.).

Dabashi is not able to show how he can pursue his radical criticism of modern philosophy without reducing any intellectual tradition, including the Muslim one, to power relations. In other words, the inevitable consequence of Dabashi's Foucaultian critique seems to be a type of Nietzscheian perspectivism with all its contradictory consequences. It can be argued that Dabashi's critique of European philosophy is hardly able to overcome the charge of subjectivism and postmodern relativism, probably the same as Said's critique of orientalism.

Iranian and Middle Eastern Politics

The strongest points of the book are Dabashi's fascinating comments on Iranian politics, especially on the 2009 pro-democracy Green Movement. The difference between Dabashi and many other post-colonialists is his full consciousness of the fact that any critique of western colonialism in Iran would be naive without a critique of the authoritarian policies of the Islamic Republic. He condemns the simplistic view of those leftist intellectuals, both in Europe and in the region, who considered the Green Movement as a movement 
sponsored by the USA or Saudis to overthrow the Iranian regime. He also condemns characterizing the Green Movement as an elite movement with no grassroots in the Iranian society. Objecting to an essay by the Palestinian intellectual-in-exile, Abu Khalil, in which he claims that it was mainly the biased media such as New York Times or Al-Arabiya who covered the story of Green Movement, Dabashi writes:

If Abu Khalil has this bizarre obsession with the American or Saudi media that he loves to hate, does that psychological fixation ipso facto deprive an entire nation of their defiance against tyranny, their agency in changing their own destiny? What a terrible state of mind to be in! Abu Khalil has so utterly lost hope in us - Arabs, Iranians, Muslims, South Asians, Africans, Latin Americans-that it does not even occur to him that maybe, just maybe, if we take our votes seriously the US and Israel may not have anything to do with it. He fancies himself opposing the US and Israel. But he has such a deeply colonized mind that he thinks nothing of us, of our will to fight imperial intervention, colonial occupation of our homelands, and domestic tyranny at one and the same time (101-02).

These statements are brilliant. Dabashi rightly observes that the Green Movement is the symbol of Iranian society's transformation into a "post-ideological" or "post-Islamist" phase (171).

Dabashi's critique of Islamophobia is also interesting. He is against attributing an essentialist meaning to Islam, blaming the militant secularists of having a naive view in this respect. The radical atheists, he claims, have closed their eyes to the fact there is an abysmal difference between the Islam of a rich Kuwaiti sheikh who is eating dinner on the Champs-Elysées, for example, and the Islam of an illegal Algerian immigrant washing the dishes in the same restaurant (281). In an essay written before the fall of Morsi in the Egypt, he criticizes the opponents of the Muslim Brotherhood among the revolutionaries who emphasized the Islamist-secular binary in the Egyptian society. By calling themselves seculars, he rightly argues, this group of the Egyptian opposition allowed the regime of Muslim Brothers to advertise itself as the main representative of Islam, and exclude others from having any claim on religion (165-68). Dabashi finds the division between Islamist and secular in the Middle East a false one. Thus, he opines that it is possible to be an 'agnostic Muslim' or even an 'atheist Muslim.' Such synthetic terms are indeed nonparadoxical. What is absent from Dabashi's thought-provoking analysis in this section is that in the case of Iran, although the Islamic state emphasizes the religious-secular binary, a new generation of religious intellectuals have been able to produce a discourse on pluralist Islam, which combines a commitment to both religion and democracy. As a result of this the hardline Islamists close to the Supreme Leader (vali-e faqib), regardless of their heavy financial and military investments, face difficulties in persuading the majority of Iranian society that religion and secularism contradict each other.

Another aspect of Dabashi's post-colonialism is his critique of Israel, and its sensitivity regarding the Palestinian cause. Furthermore, the book has an anti-American tone which sometimes tends towards exaggeration. In an essay entitled, "The Third Intifada Has Already Begun," which was written during the Arab revolts in 2011, Dabashi harshly criticizes president Barak Obama for his biased policies on the IsraelPalestine issue. Referring to Obama's talk in the general assembly of United Nations, Dabashi accuses him of being a pro-Israeli Zionist by saying,

Obama is Zionist, not Jewish. He is not the first or the last Zionist president that the United States will see. It has had all sorts of Zionist presidents, and a whole slew of Zionist would-be presidents are waiting to succeed Obama. However, the world-now from one end to the other, revolting against the indignities of this politics of despair-no longer cares. The world, shoulder to shoulder with Palestinians, is charting a different future for itself [here Dabashi refers to the Arab Spring]and the calamity code-named 'the West' cannot stop it (248).

But is it really fair to put Obama and neo-conservatives such as George W. Bush in the same basket when it comes to their policies on the Middle East? 
On different occasions, Dabashi discusses Syria after the 2011 uprising. In an atmosphere in which a majority of politicians and intellectuals both on the left and right, either among those who support Assad's brutal regime (Islamic Republic, Russia, Hezbollah, and their sympathizers) or among those who support the militant opposition (Saudi Arabia and Golf states, Turkey, United States and the Europe and so on) look to the Syrian case mostly from the perspective of real-politics in the international relations, Dabashi emphasizes that Syria should be viewed from the perspective of people with blood and flesh-to put it in the terminology of Iranian spiritualist intellectual Mostafa Malekain ${ }^{1}$ - rather than from the perspective of states. The problem with rightist and leftist intellectuals, Dabashi argues, is that they mainly look at the Syrian case from a "statist position," as if the Syrian people have no voice or existence, or as if they are merely tools in the hands of regional and global state powers. He elegantly writes:

The problem with both positions, of the left and of the right, is that they speak from a position of power or counter-power. [...] What the left and the right share, then, is an identical statism, because for both the Arab revolutions are about taking control of the state apparatus, of state power, about steering (or, more accurately, trying to steer) the falling regimes of power in their own direction. Categorically absent from the calculations of both the left and the right are the people, the real people, ordinary people, those who occupy the public space, populate it, own it. For the left and the right, these people are mere puppets who are either used, or abused for facilitating US-Saudi machinations, or else duped into supporting a revolutionary uprising that has been hijacked from them. Neither the left nor the right has the slightest trust or confidence in, or even a politically potent conception of, the public space that ordinary people physically and normatively occupy (139-40).

Dabashi's humanist approach to the events in Syria deserves appreciation, and must be considered as a model for those who think seriously about Syria. But this does not mean that his model is free from shortcomings. Dabashi is against any notion of humanitarian intervention, considering it as an excuse for colonial exploitation of the weaker states by the superpowers, particularly the USA. He even mocks the term "humanitarian intervention" (136-37). This position is partially justifiable if we consider the situation in Iraq after the 2003 American invasion or Libya after the collapse of Gaddafi. However, a total rejection of the notion of humanitarian intervention - though being a common trend among the leftist intellectuals is not free from ambiguities. What if a state is an 'outlaw' state, which systematically violates human rights and commits criminal acts such as genocide? Is it impossible to assume that the limited military intervention against the regime of Assad especially at the beginning could have reduced the number of civilian victimsmostly killed in the bombardments - whose number is estimated to be at least 300,000? Another example is Bosnia during the Balkan war of 1990s. Was the limited military intervention of the NATO not able to stop further civilian massacres?

Post-colonials such as Dabashi are totally right in claiming that the concept of humanitarian intervention can easily be misused by the expansionist colonial powers for their ends (e.g., the case of Iraq in 2003). Nevertheless, they are wrong in supposing that denying such an intervention in any case would lead to peace (e.g., the case of Bosnia). To use Rawls's category of world states, a full denunciation of humanitarian intervention by 'liberal' and 'decent' peoples would not necessarily lead to peace, but rather may pave the way for 'outlaw' dictatorial states to follow their own interventionist policies. ${ }^{2}$ Following Rawls in The Law of Peoples I think giving a limited space to humanitarian intervention in dealing with the outlaw states is superior to the political apathy endorsed by some of the intellectuals. The problem with Rawls's model, however, is that in the realpolitik of international relations which is similar to the state of nature in classical contract theories, it is highly difficult to have a reasonable consensus. For example, particularly after the advent of ISIS in Syria and the rise of Kurdish YPG as a main player in the same country, there is a 
huge disagreement among the global and regional actors such as Iran, Turkey, United States and Russia on whether the real outlaw actor is Assad, ISIS, or YPG, etc.! The real victims of this lack of consensus, of course, are the ordinary people of Syria, who hardly have any voice in the statist political environment of the international relations.

To conclude, Dabashi's book contains powerful arguments when it is the case with Iranian and Middle Eastern politics, but turns to be unpersuasive when it aims to develop radical critiques about European enlightenment.

Having a BA in Physics from Tehran University and a Masters in Philosophy of Science from Sharif University of Technology in Tehran, Dr. Meysam Badamchi earned his PhD from Luiss Guido Carli University in Rome in 2012, with a dissertation entitled Political Liberalism for Muslim Majority Societies. Since September 2013, Badamchi has been a postdoctoral research fellow at the Center for Modern Turkish Studies at Şehir University in Istanbul, partially granted by the Scientific and Technological Research Council of Turkey (TÜBİTAK). His fields of research include contemporary political theory in AngloAmerican and Muslim traditions, political liberalism, multiculturalism, and nationalism as extended to Muslim Majority context, Iranian and Turkish Political Thought, and Iranian and Turkish politics. Some of Dr. Badamchi's recent publications in peer reviewed journals include: "Political Liberalism for PostIslamist, Muslim-Majority Societies," Philosophy \& Social Criticism, 41, no. 7, 2015; "Reasonableness, Rationality and Government: the Liberal Political Thought of Mehdi Ha'eri Yazdi," Iranian Studies, 47, no. 4, 2014. He has also translated Will Kymlicka's Contemporary Political Philosophy: An Introduction (OUP, 2002) from English into Persian (under the author's supervision and in collaboration with Mohammad Mobasheri). His forthcoming book in English is: Post-Islamist Political Theory: Iranian Intellectuals and Political Liberalism in Dialogue, Springer, 'Philosophy and Politics: Critical Explorations' series, 2017. Badamchi participates in the BBC's Persian language programs as an analyst on Turkish Politics, and is a freelance writer for variety of Iranian websites in the diaspora including Radiozamaneh and Zeitoon.

1 See Mostafa Malekian, Moshtaqi va Mabjuri: Goftogu dar bab-e farbang va siyasat (Tehran: Negah-e Moaser, 1385 [2006]), 119.

2 See John Rawls, The Law of Peoples; With the Idea of Public Reason Revisited (Cambridge, Massachusetts \& London, England: Harvard University Press, 1999). 